\title{
Prosecutorial Discretion in Three Systems: Balancing Conflicting Goals and Providing Mechanisms for Control
}

\author{
Sara Sun Beale* \\ Draft June 2014
}

In regulating the authority and discretion exercised by contemporary prosecutors, national systems balance a variety of goals, many of which are in tension or direct conflict. For example, making prosecutors politically or democratically accountable may conflict with the principle of prosecutorial neutrality, and the goal of efficiency may conflict with accuracy. National systems generally seek to foster equal treatment of defendants and respect for their rights while also controlling or reducing crime and protecting the rights of victims. Systems that recognize prosecutorial discretion also seek to establish and implement policy decisions about the best ways to address various social problems, priorities, and the allocation of resources. Finally, all national systems are facing the challenge of increasing caseloads.

The United States differs from France and Germany in the training and selection of prosecutors, in the understanding of their role, and in the structure of prosecutorial authority. This chapter explores how these differences affect the balance each system has struck among the competing goals of accountability, neutrality, efficiency, accuracy, and equal treatment, how these systems differ in the availability of mechanisms to establish and implement policies, and how each is responding to the challenges of increasingly heavy caseloads.

From a comparative perspective, the most distinctive features of the U.S. system are the democratically controlled and deliberately fragmented structure of prosecutorial authority and the very broad discretion accorded to prosecutors in both charging and plea negotiations. First, the U.S. system deliberately divides prosecutorial authority between states and the federal government. Most authority is exercised within states, by more than 2,300 chief prosecutors who are generally elected at the county level. Elected prosecutors are expected to respond to local conditions and the attitudes of the community they serve, resulting in wide variances in the priorities, procedures, policies, and practices of individual prosecutorial offices. At the federal level, a different structure of political accountability provides a mechanism for establishing and implementing policy decisions and setting priorities: prosecution is an executive function, and the Attorney General and U.S. Attorneys in each district are political appointees of the president's party. While the structure of the U.S. system is designed to foster democratic control and accountability, these features raise several concerns including the potential for (1) political

\footnotetext{
* Charles L.B. Lowndes Professor, Duke Law School. Duke Law students Sam Bivins, Whitney Blazek, and Bryant Pulsipher provided outstanding research assistance that made this chapter possible. I am also indebted to Ralf Michaels, Clarisse Moreno, Julien Walther, and Thomas Weigend for their insights into the French and German systems.
} 
influences to affect prosecutorial decision making, and (2) inconsistent treatment of similar cases because of differences in priorities and procedures among prosecutorial districts. Another unique feature of the U.S. system is the wide authority possessed by prosecutors within the fragmented system. U.S. prosecutors exercise very broad discretion in both charging and plea bargaining, which are recognized as essential parts of the criminal justice system. The U.S. system efficiently processes a large number of criminal cases, but its heavy reliance on prosecutorial charging discretion to reduce the number of prosecutions and to negotiate pleas in most cases raises significant concerns about accuracy and about inconsistent treatment of similarly situated individuals. These concerns are magnified because prosecution is not a distinct career in the U.S., and no specialized training is a prerequisite in either the federal or state system. But paradoxically, although the fragmentation of the U.S. system inevitably produces disparity, the internal structure of the federal system also provides a mechanism capable of producing a uniform national approach to a very limited number of cases and issues. This allows the U.S. to comply with treaty obligations regarding foreign corruption cases, which are aggressively prosecuted by a small unit within the Department of Justice, and to require the Attorney General's approval of all death penalty cases brought in the federal system. This uniform and centralized approach, however, is the exception not the norm.

In contrast to the American system, prosecution is a well-defined civil service career in France and Germany, and the training and selection procedures are uniform and non-political. Although these common features promote prosecutorial expertise, independence, and professionalism, the French and German systems diverge in critical ways. They have distinctive ways of responding to the competing concerns of accountability, neutrality, efficiency, accuracy, and equal treatment. They differ in the availability of mechanisms to establish and implement policies. And perhaps most importantly, they respond differently to the challenges of increasingly heavy caseloads.

In France, the prosecution function is organized at a national level as a part of the judicial branch. The uniform training of prosecutors and a centralized bureaucratic structure promote consistency in standards and practices, and the placement of the prosecution function within the judicial branch reinforces strong norms of prosecutorial independence and neutrality. Because the discretion accorded to French prosecutors includes charging, case management, diversion to non-criminal alternatives, and plea negotiation, the system has the capacity to adjust to increasing caseloads. One structural feature, however, has generated considerable controversy: the executive has broad supervisory authority over the prosecution function. Although this structure provides a degree of political accountability as well as a mechanism for establishing policies and priorities, it also raises concerns about the potential for political interference with prosecutorial independence and neutrality. Controversial reforms touching on prosecutorial independence were adopted in 2013.

Germany differs from France in both the traditional conception of the prosecutor's role and the structure of prosecutorial authority, and the German understanding of prosecutorial independence and neutrality is quite distinctive. According to the traditional understanding of the German inquisitorial system, full prosecution of all known offenses is required; in this system, the prosecutor is an objective and neutral fact-finder who must seek the truth and pursue 
all possible charges. With a norm of full enforcement, the legislature sets the priorities when it enacts criminal legislation. The traditional German commitment to objective truth, full prosecution and proportional punishment is fundamentally at odds with the expansive U.S. conception of prosecutorial discretion over both charging and plea negotiations. The German system is designed to produce uniform and accurate results in all cases, but as caseloads increased it has proven impossible to sustain these ideals. Although prosecutorial discretion and plea bargaining are currently regulated by the Code of Criminal Procedure, the legislature and courts are struggling to promulgate new procedures that will permit greater efficiency while still adhering closely to the concept of objective truth and accuracy in both guilt and punishment. Prosecutors have been given statutory authority to dispose of cases summarily with little judicial oversight, and-despite the traditional norms-plea negotiations have become common. This discretion is being exercised in a decentralized system. Although German criminal law is enacted by the national legislature, virtually all of the prosecution function is allocated to the states. Accordingly, resource allocation and the establishment of prosecutorial standards and priorities occur at the state level. Moreover, as in France, there is a degree of executive control over the prosecution, though in Germany it occurs at the state level. This structure provides a mechanism for political accountability and permits policy oversight, but may allow political interference with prosecutorial decision making. Now that German prosecutors are exercising de facto prosecutorial discretion, significant regional differences, and differences between individual prosecutorial offices, have developed in the treatment of common offenses. Additionally, the delegation of authority to the states means that there is no mechanism to set national priorities or carry out international obligations (such as the obligation to prosecute foreign political corruption).

This chapter begins with a description of the U.S. approach to the structure of prosecutorial authority, the training, selection and ethos of U.S. prosecutors, and the scope of prosecutorial discretion in the U.S. Part II turns to a comparison of the French and German systems. On the basis of this foundation, Part III then considers how the three systems are resolving some of the key tradeoffs between the goals of efficiency, accuracy, democratic accountability, neutrality, consistency, and the need for mechanisms to set priorities and policies. It concludes that the structure of prosecutorial authority is continuing to play a significant role in each system's distinctive response to prosecutorial discretion. In contrast, differences in the traditional understanding of the prosecutor's role seem to be of diminishing importance as each system responds to the pressure of increasing caseloads.

\section{Prosecution in the U.S.}

The U.S. is a federal system, and both the federal government and the states have the authority to define and punish criminal violations. ${ }^{1}$ This division of responsibility permits significant differences between federal and state practices, and-as noted below-between and within individual states. This variability is enhanced by traditions concerning the training and

\footnotetext{
${ }^{1}$ Under the U.S. constitution, the states have plenary police powers, but pursuant to authority delegated to the federal government, the federal government may implement criminal laws by passage and enforcement. See generally Norman Abrams ET AL., FEDERAL CRiminal LAW AND ITS ENFORCEMENT 18-27 (5th ed. 2012).
} 
selection of both individual prosecutors and chief prosecutors. In general, the U.S. systems promote some form of democratic accountability, and the fragmentation of authority virtually guarantees that different offices will develop different priorities and practices.

\section{A. The structure of prosecutorial authority and the education and selection of prosecutors}

The U.S. systems for the selection and retention of chief prosecutors are designed to create political accountability, though the federal and state systems structure this accountability differently. U.S. Attorneys are political appointees who report to the Attorney General-a political appointee and member of the president's cabinet - and to other senior political appointees within the Department of Justice. At the state level there is some variation, but generally district attorneys and state attorneys general run for elections, often on a partisan ballot.

At the federal level, democratic accountability is achieved through a system of political appointments. The federal constitution lodges all executive power in the president. ${ }^{2}$ The president's prosecutorial authority (part of the power to "execute" federal law ${ }^{3}$ ) has been delegated to approximately one hundred individuals - the Attorney General, several other senior officials in the Justice Department, and the United States Attorneys in each of the 94 federal judicial districts - who are nominated by the president, subject to Senate confirmation, and removable by the president at any time. ${ }^{4}$

In contrast to the federal model of a unitary executive, most states disaggregate the responsibility for both law enforcement and prosecution, and they allocate both to elected officials. ${ }^{5}$ Most chief prosecutors serve county-based jurisdictions, ${ }^{6}$ and in 2005 there were 2,344 state prosecutor's offices. ${ }^{7}$ Forty seven states elect their chief prosecutors. ${ }^{8}$

\footnotetext{
${ }^{2}$ U.S. ConST., art. II, § 1. (providing "[t]he executive power shall be vested in a President of the United States of America.").

${ }^{3}$ See U.S. CONST., art. II, § 3 (president "shall take care that the laws be faithfully executed").

${ }^{4}$ In addition to the Attorney General, the Deputy Attorney General and the Assistant Attorneys General for the Criminal, National Security, Civil Rights, Environmental, Tax, and Antitrust Divisions have prosecutorial responsibilities. Because the Associate Attorney General supervises some of these divisions, that office can also be characterized as one with prosecutorial authority. For a discussion of the allocation of responsibility between the U.S. Attorneys and the officials at Main Justice, Sara Sun Beale, Rethinking the Identity and Role of United States Attorneys, 6 OHIo St. J. CRIM. L. 369, 398-409 (2009).

${ }^{5}$ For a discussion of the historical development of the current state systems, see JOAN E. JACOBY, THE AMERICAN PROSECUTOR: A SEARCH FOR IDENTITY 3-43 (1980). Prosecutors were not elected in the early republic, and indeed they were generally regarded as minor figures closely related to the courts. $I d$. at $21-22,24$. The democratic revival that accompanied the election of Andrew Jackson led to the expansion of elected offices, including district attorneys, and by the Civil War the position was perceived to be executive in character. Id. at 22, 26-27. By 1912, all 48 states had a prosecuting attorney office, and only Connecticut, New Jersey, Delaware, Rhode Island, and Florida did not elect their prosecutors. Id. at 26.
} 
U.S. prosecutors must have a law degree, but no specialized training is required. ${ }^{9}$ Prosecution is not generally viewed as a distinct career. Many litigators work for a period of time in a prosecutor's office to get courtroom experience, and most prosecutors' offices have a high degree of turnover. Each office establishes its own hiring procedures and criteria. ${ }^{10}$ For example, some offices hire graduates who have just finished law school, but others seek candidates with some experience. ${ }^{11}$ Although the absence of a distinct educational or career track removes some structural sources of shared values and experience, the adversarial process itself appears to serve as a catalyst for the development of a distinct prosecutorial identity. ${ }^{12}$

${ }^{6}$ In three states-Alaska, Connecticut, and Delaware - the attorney general is the chief prosecutor in a unified statewide system. The attorneys general of Connecticut and Delaware are elected, and the small size of these states may make their responsibilities as chief prosecutor comparable to some degree to those of the chief prosecutors in the largest counties or metropolitan areas.

${ }^{7}$ Steven W. Perry, Bureau of Justice Statistics, National Survey of Prosecutors: Prosecutors in State Courts, 2005, at 1 (2005), available at http://bjs.ojp.usdoj.gov/content/pub/pdf/psc05.pdf. The title of the chief prosecutor varies from state to state; the most common titles are district attorney, prosecuting attorney, county attorney, but other titles are used as well. See id., Appendix, at 11.

${ }^{8}$ Delaware, Rhode Island, Alaska, New Jersey, and Connecticut do not elect their local prosecutors. Delaware and Rhode Island are so small that a system of local prosecutors may be infeasible. Joan E. Jacoby, The American Prosecutor in Historical Context, 39 Prosecutor 28, 32 (May/June 2005). In New Jersey, the governor appoints the district attorney, whereas in Connecticut an independent constitutional agency, the Criminal Justice Commission, does so. Id.; see also State of Connecticut Criminal Justice Commission, http://www.ct.gov/cjc/site/default.asp. The Alaska attorney general is appointed by the governor and must be confirmed by the state legislature. Jacoby, supra, at 33; see also William Yardley, Legislators Reject Palin Pick for Alaska Attorney General, N.Y. TIMES, Apr. 17, 2009, at A18 (noting that the Alaska legislature voted 35 to 23 to reject Governor Sarah Palin's attorney general nominee, Anchorage lawyer Wayne A. Ross).

${ }^{9}$ The U.S. Department of Justice and some individual chief prosecutors do conduct staff training. The Department maintains a national advocacy training center in South Carolina, which trains more than 10,000 federal, state, and local prosecutors and litigators in advocacy skills and management of legal operations annually. For more information on the National Advocacy Center, see http://www.justice.gov/usao/training/.

${ }^{10}$ For an excellent discussion of the variation among prosecutors' offices and how structural differences may affect the behavior of prosecutors, see Kay L. Levine \& Ronald F. Wright, Prosecution in 3-D, 102 J. CRIM. L. \& CRIMINOLOGY 1119 (2013)

${ }^{11}$ Id. at 1144-46 (contrasting office that hires only veteran prosecutors with another that hires new law school graduates).

${ }^{12}$ Research on the causes of wrongful convictions in the U.S. has identified the problem of "tunnel vision," i.e., unconscious cognitive biases that affect both police and prosecutors, which become stronger, rather than weaker, as prosecutors gain experience. There is evidence that these biases affect even prosecutors who are most committed to the ideal of doing justice, and that the structure of the U.S. adversarial system exacerbates these natural biases. See generally 


\section{B. Prosecutorial Discretion}

U.S. prosecutors have extraordinarily wide discretion within a system that deliberately fragments prosecutorial authority. The state systems generally lack mechanisms to require or even promote prosecutorial uniformity. Variations reflecting local conditions and the preferences of the electorate in different states (or different counties within a state) are understood to serve the values of federalism and democratic accountability. The federal system also allocates significant discretion to the U.S. Attorneys in the 94 judicial districts, but it balances that distributed authority with structural and administrative mechanisms that promoteor in some cases require- prosecutorial uniformity in certain kinds of prosecutions.

The courts and commentators alike recognize that U.S. prosecutors have wide discretion in determining whether and what criminal charges should be brought, and this discretion is subject to virtually no legislative or judicial oversight. ${ }^{13}$ For example, in a 1979 decision the United States Supreme Court stated:

This Court has long recognized that, when an act violates more than one criminal statute, the Government may prosecute under either so long as it does not discriminate against any class of defendants. Whether to prosecute and what charge to file or bring before a grand jury are decisions that generally rest in the prosecutor's discretion. ${ }^{14}$

U.S. prosecutors have equally broad discretion in deciding whether to offer or agree to a plea bargain, and, if so, what the terms of the agreement will be. ${ }^{15}$ Indeed, contemporary commentators have recognized that the U.S. criminal justice system now operates as an

Keith A. Findley \& Michael S. Scott, The Multiple Dimensions of Tunnel Vision in Criminal Cases, 2006 WIS. L. REv. 291. See also Susan Bandes, Loyalty to One's Convictions: The Prosecutor and Tunnel Vision, 49 How. L.J. 475, 486-87, 490 (2006) (noting that U.S. prosecutors have constant interaction with the police, victims, and prosecution witnesses, but little contact with the defendant, his family and friends, and defense counsel and this encourages empathy and loyalty within the prosecution team but isolation from-and often negative attitudes toward - the defense).

${ }^{13}$ The courts do recognize that prosecutors may not base their decisions on suspect constitutional criteria, such as race, but even that limitation is virtually impossible to enforce because of the crippling evidentiary burden the defense must meet even to gain discovery of evidence that might support such a claim. See generally Richard H. McAdams, Race and Selective Prosecution: Discovering the Pitfalls of Armstrong, 73 CHI. L. REv. 605 (1998) (analyzing the seemingly "insuperable" evidentiary hurdles for defendants seeking to prove selective prosecution after the Supreme Court's decision in United States v. Armstrong, 517 U.S. 4546 (1996).

${ }^{14}$ United States v. Batchelder, 442 U.S. 114, 123-24 (1979) (citations omitted.)

${ }^{15}$ See generally Wayne R. LAFAVE ET AL., CRiminal Procedure 1034 (5th ed. 2009) (stating that "plea bargaining is an aspect of the prosecutor's broad charging discretion whereunder he is permitted to decide when and whether to institute criminal proceedings, or what precise charge shall be made, or whether to dismiss proceedings once they are brought"). 
administrative system, in which virtually all critical decisions are made by prosecutors, not an adversarial trial-based system. ${ }^{16}$

Given the nature of the federal system and the deliberate fragmentation of prosecutorial authority, it is not surprising that prosecutorial priorities and practices differ markedly among the states and also among local prosecutors within a single state. Indeed, within most states no structure exists to require or promote uniform enforcement among local prosecutors.

Enforcement of the death penalty provides a highly visible example. Prosecutors are expected to reflect and accommodate community attitudes, especially on such hot button issues, ${ }^{17}$ and enforcement patterns vary widely in the 32 states that have the death penalty. The vast majority of death sentences originate in only five of these states. ${ }^{18}$ Even within the busiest death penalty states, death sentences were clustered in approximately $1 \%$ of counties from 2004 to $2009 .^{19}$ Prosecutorial practices have played a significant role in producing this pattern, though it also reflects a variety of other factors including jury behavior and the success of various legal challenges. Enforcement of mandatory minimum sentencing laws reveals a similar pattern. For example, after California passed the nation's harshest three strikes sentencing law, enforcement varied significantly from county to county. ${ }^{20}$ Gil Garcetti, the Los Angeles District Attorney, took a hard line and issued written instructions stating that all prosecutors were "duty-bound" to press for three strikes sentences. ${ }^{21}$ In a subsequent election Garcetti was defeated by a candidate who campaigned on a promise to use proportionality in deciding whether to charge a third strike. ${ }^{22}$

Within some individual offices in the state systems, there are mechanisms to promote uniformity. At the county or district level, it appears that many individual offices have internal policies or guidelines, but these are not generally made available to the public and little is known about either their content or administration.

${ }^{16}$ See generally Gerard E. Lynch, Our Administrative System of Criminal Justice, 66 FORDHAM L. REV. 2117 (1998).

${ }^{17}$ New Hampshire provides an interesting counter example. The State Attorney General's Office is responsible for initiating and conducting prosecutions for capital murder, and it has a broad consultative process for determining whether the criteria for initiating a capital murder prosecution are met as well as special training for prosecutors handling capital cases. See FINAL

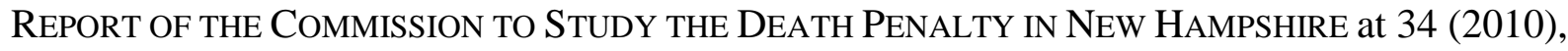
available at http://www.deathpenaltyinfo.org/documents/NHDeathPenalty.pdf. New Hampshire's statute is one of the narrowest in the U.S., and it had only two death penalty trials in the last 50 years, leading to a single death sentence. $I d$. at 14 .

${ }^{18}$ Robert J. Smith, The Geography of the Death Penalty and Its Ramifications, 92 B.U. L. REV. 227, 230 (2012).

${ }^{19}$ Id. at 233 (this $1 \%$ of countries accounts for $44 \%$ of death penalty sentences).

${ }^{20}$ Sara Sun Beale, The Story of Ewing: Three Strikes Laws and the Limits of the Eighth Amendment Proportionality Review, in CRIMINAL LAw STORIES 427, 434 (Donna Coker \& Robert Weisberg, eds., 2013) (noting a study finding variance between much higher frequencies in Los Angeles than in Alameda and San Francisco counties).

${ }^{21} \mathrm{Id}$.

${ }^{22}$ Id. at 434-35. 
At the federal level, all prosecutors are part of the executive branch headed by the president, and this structure provides a framework in which national priorities can be set and policies and procedures established. (Note, however, that because the constitution delegates plenary police powers to the states, these policies and procedures apply only to federal prosecutions, which make up less than $10 \%$ of U.S. felony cases. ${ }^{23}$ ) Perhaps the most importantand controversial-such policy was a general directive (modified in later administrations) requiring all federal prosecutors to prosecute all defendants for the most serious readily provable offense. $^{24}$ More recently, in 2010 Attorney General Eric Holder instructed all federal prosecutors to conduct "an individualized assessment of the extent to which particular charges fit the specific circumstances of the case, are consistent with the purpose of the Federal criminal code, and maximize the impact of Federal resources on crime." ${ }^{25}$ Subsequently, in 2013 Attorney General Holder instructed federal prosecutors not to trigger mandatory sentencing enhancements for low-level non-violent drug offenders. ${ }^{26}$

The United States Attorneys' Manual also provides guidance on the exercise of prosecutorial discretion in the federal system. ${ }^{27}$ Most of its provisions are so broad and general that they do little more than establish a framework for decision-making in most individual cases. However, centralized review and approval are required for a few kinds of federal cases: cases eligible for the federal death penalty, ${ }^{28}$ charges under the Foreign Corrupt Practices Act (FCPA $)^{29}$ and the Racketeering and Organized Crime (RICO) statute, and criminal tax charges. ${ }^{30}$

${ }^{23}$ The number of prosecutions in each jurisdiction and percentage of the total that are brought in the federal courts varies from year to year, but federal prosecutions are less than $10 \%$ of the total. See generally ABRAMS, ET AL., supra note 1 at 13.

${ }^{24}$ For a discussion of this directive, see Kate Stith, The Arc of the Pendulum: Judges, Prosecutors, and the Exercise of Discretion, 117 Yale L.J. 1420, 1440-42 (2008) (describing origins of the "Thornburg Memorandum," which "sought to centralize the exercise of prosecutorial power essentially by delegitimating the exercise of prosecutorial discretion").

${ }^{25}$ Memorandum from Attorney General Eric Holder to All Federal Prosecutors (Aug. 12, 2013), available at http://www.justice.gov/oip/holder-memo-charging-sentencing.pdf (discussing the department policy on charging and sentencing).

${ }^{26}$ Memorandum from Attorney General Eric Holder to the United States Attorneys and Assistant Attorney General for the Criminal Division (Aug. 12, 2013) (instructing prosecutors not to charge drug quantities that would trigger mandatory minimum sentences for low-level nonviolent defendants with no significant criminal history), available at http://www.justice.gov/oip/docs/ag-memo-department-policypon-charging-mandatoryminimum-sentences-recidivist-enhancements-in-certain-drugcases.pdf.

${ }^{27}$ See generally Title 9 of THE UNITED STATES ATTORNEYS MANUAL (hereinafter USAM), available at http://www.justice.gov/usao/eousa/foia_reading_room/usam/title9/title9.htm.

${ }^{28}$ USAM $\$ \S 9-10.010$ et seq. (setting forth procedures for capital case review, including review by capital case unit at Main Justice and final decision by the Attorney General).

${ }^{29} I d$., USAM $\S 9-47.110$ (requiring information about possible violations of FCPA to be brought to the attention of the Fraud Section in the Criminal Division, and providing for trial of FCPA cases unless otherwise provided for by the head of the Criminal Division). 
There are also more detailed guidelines stating the factors to be considered and the procedures to be followed when a corporation may be prosecuted. ${ }^{31}$

\section{Prosecution in France and Germany}

Although prosecution is a career appointment in both France and Germany, there are significant differences in their conception of the prosecutor's role and the organization of the prosecutorial function. In France, the prosecutorial function is organized at the national level, and the centralized bureaucratic structure reflects the continuing influence of Napoleonic reforms. Although individual prosecutors are understood to have significant charging discretion, mechanisms also exist to set national priorities, promote uniform practices, and develop specialized expertise and authority for certain types of cases. Though the French characterize prosecutors as part of the judiciary, concerns about interference with prosecutorial independence led to reforms in 2013. Commentators disagree about the significance of the changes. In particular, it is unclear whether the reforms have significantly bolstered the independence of French prosecutors in politically salient white collar cases. In contrast, the exercise of prosecutorial discretion is difficult to reconcile with the traditional German view of the prosecutor's role as an objective fact finder in an inquisitorial system based on the principle of mandatory prosecution. Dramatic caseload increases have made full adherence to these traditional norms impossible, and in effect German prosecutors are now exercising both charging and bargaining discretion. Statutory procedures allow prosecutors to dispose of certain cases with little judicial input, and statutory authority now exists for a limited form of negotiated confession. It is questionable whether new statutory requirements for negotiated guilty pleas will be followed. Germany delegates almost all enforcement authority to its sixteen states (Länder), and within states the prosecution function is part of the ministry of justice. As German prosecutors exercise more discretion, this structure raises concerns about political interference with prosecutorial decision making, and the delegation of authority means Germany has no mechanism for setting national enforcement priorities.

\footnotetext{
${ }^{30} I d ., \S \S 9-10.010$ et. seq. (requiring all cases in which the death penalty might be applicable to be submitted to a national committee appointed by the Attorney General, which can override the recommendation of the U.S. Attorney), 9-110.200 et seq. (requiring U.S. Attorney seeking to bring RICO charges to submit a detailed prosecutorial memorandum meeting stringent requirements to obtain approval from the Criminal Division), and §6-4.200 (requiring U.S. Attorney to obtain approval of the Tax Division before bringing criminal tax charges).

${ }^{31}$ Id., $\S 9-28.100$ et. seq. (Principles of Federal Prosecution of Business Organizations).
} 


\section{A. France}

French prosecutors $^{32}$ are part of the career judiciary, the magistrature. ${ }^{33}$ The judiciary is divided into two bodies: the standing judiciary (which includes prosecutors), and the sitting judiciary (which includes trial judges and juges d'instruction or investigating magistrates). Entrance to the magistrature is by a competitive examination, followed by training at a national school, the Ecole nationale de la magistrature (ENM). ${ }^{34}$ The common training of future prosecutors, trial judges, and investigating magistrates creates ties of both "collegiality and ideology." 35 Magistrats may move from the standing to the sitting judiciary, or vice versa. They are part of what one author described as a national corps of highly educated bureaucrats, a " nobility.",36

The national structure of the judiciary, including the parquet, reflects the centralization that was part of the Napoleonic reforms. ${ }^{37}$ These reforms adopted a military model for the civil service, including hierarchy and the uniform enforcement of clear rules. ${ }^{38}$ The government structure also reflects a fear of judicial power, and an effort to limit the judicial role to the declaring and applying the text of the law. ${ }^{39}$

Although the sitting judiciary operates independently of the executive branch of the French government, the Minister of Justice has the ultimate authority over the parquet. ${ }^{40}$ This structure provides political accountability and may also help produce consistency in prosecutorial practices and standards. The French Code of Criminal Procedure defines the Minister of Justice's role as "conducting the policy of public action determined by the government. . . ensur[ing] the consistency of its application."41 In carrying out this role, the Justice Minister may promulgate written guidelines to the parquet and can request that specific violations of the law be prosecuted. ${ }^{42}$ The Justice Minister may also "move, promote or transfer prosecutors and [] nominate her own political allies." $" 43$ This structural feature has been controversial, and, as noted below, reforms were adopted in 2013.

The Minister of Justice commands the Attorney General (procureur général), who in turn "ensure[s] the application of the criminal law to the fullest extent" by "organizing and coordinating the actions of the prosecutors of the Republic, regarding both prevention and

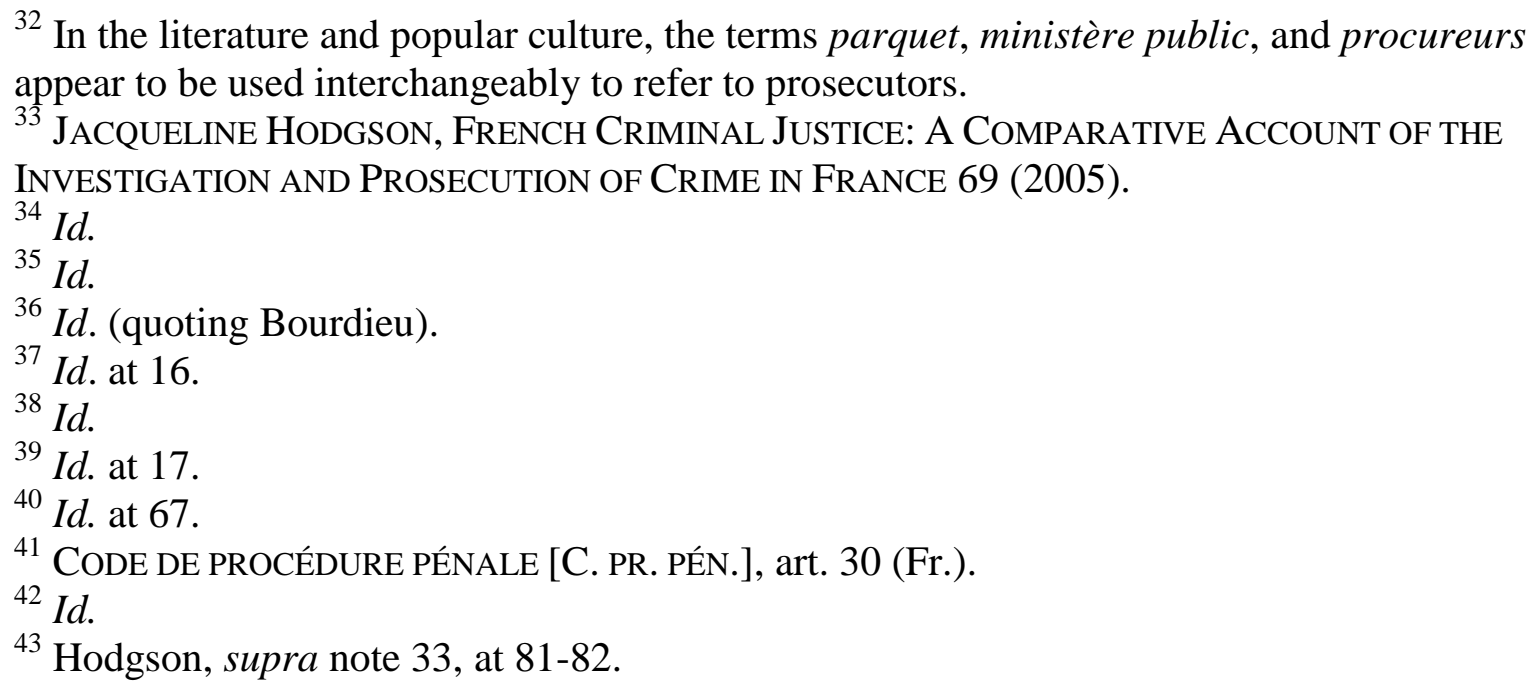


punishment of offenses under the criminal law and the conduct of public policy action by prosecutors. ${ }^{44}$ The term "attorney general" can be misleading. In France, there is an attorney general appointed to the Cour de cassation, ${ }^{45}$ which is the highest appeals court for questions of law, and attorneys general are also appointed in each court of appeal, one of which sits in every département in France. ${ }^{46}$ Prosecutors in the courts of original jurisdiction (e.g., cours de assises, for felonies) are expected to follow the orders of the attorneys general of the appeals court in their jurisdictions. ${ }^{47}$ The attorneys general are nominated in a political process, which has led to concern that political control can compromise the parquet's appearance of independence. ${ }^{48}$

Although Article 64 of the French Constitution nominally guarantees the independence of all magistrates, its guarantee does not apply to prosecutors. ${ }^{49}$ The Minister of Justice's ability to issue instructions to prosecutors, combined with the influence she has over the trajectory of the prosecutor's career, means that French prosecutors lack full independence. ${ }^{50}$

Two controversial reforms adopted in 2013 sought to address the ability of the Minister of Justice to interfere with individual prosecutions, as well as special concerns with the integrity of politically sensitive white collar prosecutions. On July 25, 2013, the French National Assembly passed a law that modified the French Code of Criminal Procedure. ${ }^{51}$ As amended, Article 30 forbids the Minister of Justice from issuing instructions to prosecutors in individual cases. ${ }^{52}$ Previously, Article 30 was interpreted to permit such instructions. ${ }^{53}$ Although it appears

${ }^{44}$ See C. PR. PÉN., art. 35.

${ }^{45}$ See LA Ministere DE LA JuSTICE, Procureur, available at http://www.justice.gouv.fr/leministere-de-la-justice-10017/direction-des-services-judiciaires-10022/procureur-26218.html (last visited Mar. 18, 2014).

${ }^{46}$ See id.

${ }^{47}$ Richard J. Terrill, WORLd Criminal Justice Systems: A COMPARATIVE SurVey 162 (Matthew Bender \& Co., $7^{\text {th }}$ ed., 2009).

${ }^{48}$ Jacqueline Hodgson, Hierarchy, Bureaucracy, and Ideology in French Criminal Justice: Some Empirical Observations, 29 Law \& Soc'y Rev. 227, 234 n. 30 (2002) (also criticism of the fact that the council which appoints trial judges and judges $d$ 'instruction plays no role in the selection of attorneys general).

${ }^{49}$ Hodgson, supra note 33, at 76.

${ }^{50} \mathrm{Id}$. Professor Hodgson notes that while ministerial instructions concerning a case are required to be put in writing and placed in the case dossier, "less formal communications continue to be issued and are often treated as formal instructions." Id. at 75-76.

${ }^{51}$ Loi no. 2013-669 du 25 juillet 2013 relative aux attributions du garde des sceaux et des magistrats du ministère public en matière de politique pénale et de mise en œuvre de l'action publique [Law no. 2013-669 of 25 July 2013 concerning the powers of the Minister of Justice and public prosecutors in criminal policy and implementation of policy], available at http://www.legifrance.gouv.fr/affichTexte.do?cidTexte=JORFTEXT000027751362.

${ }^{52}$ C. PR. PÉN, art. 30 (version in force July 27, 2013), available at http://www.legifrance.gouv.fr/affichCodeArticle.do;jsessionid=331199D2BF156C59EE564125F oC20C76.tpdjo14v_1?idArticle $=$ LEGIARTI000027753870\&cidTexte $=$ LEGITEXT000006071154 \&categorieLien $=i d \&$ dateTexte $=20140113$.

${ }^{53}$ Prior to 2013, the Code was generally interpreted to permit the Minister of Justice to order 
at first glance that Article 35 might allow the Minister of Justice to make an end-run around the prohibition on individual instructions by operating through the attorneys general, the corresponding modifications in that statute appear to demonstrate the National Assembly's intent to foreclose even indirect ministerial control over individual cases. ${ }^{54}$ In December 2013 the legislature also passed a controversial law creating a new prosecutorial position at the Tribunal de Grand Instance in Paris with concurrent jurisdiction over complex financial crimes. ${ }^{55}$ Although the new law was presented as part of an effort to fight white collar crime, critics attacked the measure on several grounds. First, they charged that it was redundant and unnecessary because specialized financial crime courts already exist in France. ${ }^{56}$ Second, the top magistrates' unions voiced concerns that the centralization of financial crime cases could undermine prosecutorial independence and lead to greater executive interference. ${ }^{57}$ Furthermore, due to a provision of the law known as the "Bercy lock," prosecutors will not have the ultimate say regarding whether a tax evasion should be prosecuted. ${ }^{58}$ Instead, a committee controlled by the Budget Minister will ultimately make that decision. ${ }^{59}$ Third, some commentators predicted a bureaucratic nightmare for the new financial prosecutor, given that she would share jurisdiction

written submissions in individual cases, as well as dismissal, release, or acquittal. See Pascal Lemoine, Ministère Public [:] Organisiation. Attribution du garde des Sceaux, in JURRISCLASSEUR PROCÉDURE PÉNALE para. 64, Feb. 26, 2005.

${ }^{54}$ Compare C. PR. PÉN art. 35 (version in force from March 7, 2007 to July 27, 2013) (declaring that attorney general coordinates the actions of prosecutors and the conduct of public policy within his jurisdiction) with C. PR. PÉN art. 35 (version in force on July 27, 2013) (the attorney general "clarifies" and "adapts" the instructions of the minister of justice, but only "assesses" their application by prosecutors), available at http://www.legifrance.gouv.fr/affichCodeArticle.do;jsessionid=331199D2BF156C59EE564125F $\underline{0 \text { C20C76.tpdjo14v_1?idArticle }=\text { LEGIARTI000027753880\&cidTexte=LEGITEXT00000607115 }}$ 4\&categorieLien $=$ id\&dateTexte $=20140113$.

${ }^{55}$ Loi organique $\mathrm{n}^{\circ}$ 2013-1115 relative au procureur de la République financier (December 6, 2013), available at http://legifrance.gouv.fr/affichTexte.do;jsessionid=45D0E8B55F21B4BBC33C241AC18E0D9C .tpdjo16v_1 ?cidTexte=JORFTEXT000028278945\&dateTexte=\&oldAction=rechJO\&categorieLi en=id\&idJO=JORFCONT000028278922.

${ }^{56}$ E.g., Un procureur spécialisé en fraude fiscale, [A prosecutor specialized in tax fraud], LE FigARO (July 5, 2013), available at http://www.lefigaro.fr/flash-eco/2013/05/07/9700220130507FILWWW00359-un-procureur-specialise-en-fraude-fiscale.php.

${ }^{57}$ Laurence de Charrette, Le parquet spécialisé ne convainc pas les magistrats, [The specialized prosecutorial corps does not convince the magistrates], LE FIGARO (Nov. 4, 2013), available at http://www.lefigaro.fr/politique/2013/04/10/01002-20130410ARTFIG00985-moralisationhollande-annonce-un-procureur-dedie-aux-affaires-financieres.php.

${ }^{58}$ Quatre questions sur le procureur financier, [Four questions about the financial prosecutor], LE MONDE (June 12, 2013), available at http://www.lemonde.fr/societe/article/2013/12/05/quatre-questions-sur-le-procureurfinancier 3525335 3224.html.

${ }^{59} \mathrm{Id}$. 
in Paris with the general prosecutor. ${ }^{60}$ These problems are so glaring that at least one observer suggested that the law was not a true reform, but rather that the impetus for the law was to punish the general prosecutor for his overly zealous investigation of a cabinet member for tax evasion. ${ }^{61}$

Unlike Germany (discussed below) France does not recognize the principle of mandatory prosecution, and it is for the prosecutor to determine what action should be taken in cases referred to her. ${ }^{62}$ As Jacqueline Hodgson explains:

She exercises an important discretion in deciding whether or not to prosecute; in selecting the precise charges to be brought (which also determine the level of trial court and whether or not the case will be investigated by the juge d'instruction); and in determining whether to take no further action. More recently, the parquet has extended this discretion in making use of a number of alternatives to prosecution and trial, enabling it to regulate further the increasing number of cases with which it is required to deal. ${ }^{63}$

French prosecutors also have case management discretion that permits them to treat an offense summarily as a low level violation (referred to as correctionalisation), as well as the power to initiate alternatives to trial, including mediation and a range of alternative sanctions. ${ }^{64}$ In 2002 , Hodgson reported that nationwide French prosecutors had declined to take further action in approximately $50 \%$ of the cases in which there was evidence that a crime had been committed and a suspect had been named. ${ }^{65}$ She also found "wide regional variations." ${ }^{66}$ More recently, she reported an "exponential" growth in the number of cases disposed of by composition pénale, an alternative to prosecution which allows the prosecutor to propose a range of measures to an accused who admits the offense, such as community service, payment of compensation, and participation in drug rehabilitation. ${ }^{67}$ Additionally, since 2004 French prosecutors have had

${ }^{60}$ Paule Gonzalez, Juges et politiques contestent la création d'un procureur national pour les délits financiers [Judges and politicians contest the creation of a national prosecutor for financial crimes], LE FIGARO (June 11, 2013), available at http://www.lefigaro.fr/actualitefrance/2013/11/05/01016-20131105ARTFIG00552-juges-et-politiques-contestent-la-creation-dun-procureur-national-pour-les-delits-financiers.php.

${ }^{61} I d$.

${ }^{62}$ Hodgson, supra note 48, at 233.

${ }^{63}$ Id. (footnotes omitted). See also Goldstein \& Marcus, The Myth of Judicial Supervision in Three "Inquisitorial” Systems: France, Italy, and Germany 87 YALE L. J. 240, 247 (1977) (stating that "The French prosecutor is not subject to a requirement of mandatory prosecution, no matter how serious the offense. He may rely on the "expediency" (or "opportunity") principle to dismiss a case for either evidentiary or policy reasons; he need not hide "real" reasons behind "official" ones, or even report his decision to the court.")

${ }^{64}$ Jacqueline Hodgson, Guilty Pleas and the Changing Role of the Prosecutor in French Criminal Justice, in The Prosecutor In Transnational PERSPECTIVE 116, 124-26 (Erik Luna

\& Maryanne L. Wade, eds., 2012).

${ }^{65}$ Hodgson, supra note 48, at 233 n. 27.

${ }^{66} I d$

${ }^{67}$ Hodgson, supra note 64, at 125-26 (noting increase from 1,500 cases in 2001 to more than 73,000 cases in 2009). 
statutory authority to enter into a form or plea or sentence bargaining (called comparution sur reconnaissance prealable de culpabilité, or $\mathrm{CRCP}$ ), which now applies to offenses carrying a fine or term of imprisonment of ten years or less. ${ }^{68}$ A CRPC sentence may not be more than one year's imprisonment or half of the maximum sentence for the offense. ${ }^{69}$ Although no provision was made for negotiation over CRPC sentences (and negotiation was specifically excluded in an early Ministry of Justice circular), in practice CRPC sentences are negotiated. ${ }^{70}$ In 2009 , there were 77,530 CRPC sentences, accounting for 11.5 percent of total prosecutions. ${ }^{71}$

As noted in the previous section, the Minister of Justice can issue general written guidelines (often referred to as "circulars") to bring about consistency in the application of the law. The circulars are generally made available on the Ministry of Justice internet site. For example, a recent circular on "The Fight Against Fraud" 72 identified three national priorities: VAT (value added tax) fraud, transnational social fraud, and illegal internet gambling. It instructed prosecutors to make "a special effort" in matters of financial recovery and financial sanctions. It also made illegal work a priority at the local level, targeting the following occupational sectors: building and public works, hotels, cafes and restaurants, services (including domestic services), seasonal agricultural work, and live performances. Finally, it singled out welfare fraud as meriting a criminal response but also encouraged alternatives to formal criminal prosecution. Recent circulars have also been issued to deal with cases involving a wide range of topics including juveniles, gangs, cults, and drug offenses.

\section{B. Germany}

German prosecutors (and judges) are appointed administratively to career positions after completing their legal education. ${ }^{73}$ All lawyers and judges must also undergo substantial postgraduation, on-the-job training during a two-year internship. ${ }^{74}$ Thereafter lawyers may practice anywhere in Germany. ${ }^{75}$ For the first three years, appointed prosecutors and judges work at various court levels before receiving tenure. ${ }^{76}$

${ }^{68}$ Code De Procédure PÉNALe [C. PR. PÉN.] art. 495-7 (Fr.).

${ }^{69}$ Hodgson, supra note 64, at 127.

$70 \mathrm{Id}$.

${ }^{71} I d$. at 127 n. 36.

${ }^{72}$ Maryvonne Caillibotte, BuLlETIN OFFICIEL Du Minstère DE LA JUSTICE ET DES LIBERTÉS, Circulaire du 7 juin 2011 relative à la mise en ouvre du plan national de coordination de la lutte contre la fraude pour 2011 [Circular concerning the implementation of the national plan for the fight against fraud], available at http://www.textes.justice.gouv.fr/art_pix/JUSD1115645C.pdf.

${ }^{73}$ Cornelius Nestler, Sentencing in Germany, 7 BUFF. CRIM. L. REV. 109, 110 (2003). Judges on the Federal Constitutional Court are selected by a legislative process. PETER MURRAY \& ROLF STÜRNER, GERMAN CIVIL JustiCE 8 (2004); GG art. 94(1).

${ }^{74}$ DeUTSChES Richtergesetz [DRiG] [German Statute on Judges] $§ 5 \mathrm{a}, 5 \mathrm{~b}, 1$ BundESGESETZBLATT 2515 (2011); BundESRECHTSANWALTSORDNUNG [BRAO] [Federal Statute on Attorneys] § 4, 1 BundESGESETZBLATT 2515 (2011).

${ }^{75}$ BRAO $\$ 5$.

${ }^{76}$ Richard S. Frase \& Thomas Weigend, German Criminal Justice as a Guide to American Law Reform: Similar Problems, Better Solutions?, 18 B. C. INT'L \& COMP. L. REV. 317, 320 (1995). 
Germany has strong norms of prosecutorial objectivity and neutrality coupled with a traditional norm of mandatory prosecution. The German prosecutor's duty to be objective has been called "an 'elementary and indispensable demand of a procedure based on the rule of law.",77 Germans like to say that their prosecutors are "the most objective agency in the world." "78 This is consistent with the German inquisitorial tradition, which aims to discover the objective truth rather than to preserve the parties' ability to argue their cases fairly. German criminal law and procedure are designed around the principles of investigation (Instruktionsprinzip or Ermittlungsgrundsatz) and factual truth (Prinzip der materiellen Wahrheit). ${ }^{79}$ German criminal procedure often reflects this focus on objective truth-seeking. Before charges are filed, the police and prosecutors investigate alleged crimes. ${ }^{80}$ Prosecutors must investigate evidence weighing both for and against conviction. ${ }^{81}$ However, it should be noted that after a prosecutor has determined that criminal charges are warranted, she takes on an adversarial role at the trial. ${ }^{82}$ Additionally, both German police and prosecutors are subjected to the principle of legality (Legalitätsprinzip). ${ }^{83}$ This principle (which applies only to natural persons) requires the investigation and prosecution of every crime for which there exists a sufficient factual basis. ${ }^{84}$

Germany is civil law republic composed of sixteen states (Länder). ${ }^{85}$ Although criminal law is codified entirely at the national level, ${ }^{86}$ it is implemented almost entirely by the states. ${ }^{87}$ State ministries of justice supervise the prosecution service as well as the judicial and

77 Thomas Weigend, A Judge By Any Other Name? Comparative Perspectives on the Role of the Public Prosecutor, in The Prosecutor in Transnational Perspective 377, 381 n. 21(Erik Luna \& Maryanne L. Wade, eds., 2012) (quoting Beulke).

${ }^{78} I d$. at 382.

${ }^{79}$ Rodolphe Juy-Birmann \& Jörg Biermann, The German System, in EUROPEAN CRIMINAL PROCEDURES 309 (Mireille Delmas-Marty \& J.R. Spencer eds., 2002).

${ }^{80} \mathrm{StPO} \S 160(1)$.

${ }^{81}$ StPO $§ 160(2)$.

${ }^{82}$ Weigend, supra note 79, at 382.

${ }^{83}$ Markus D. Dubber, Criminal Law in Comparative Context, 56 J. LEGAL EduC. 433, 438-39 (2006).

${ }^{84}$ StPO $\S 152$. See also Dubber, supra note 85, at 438 ("In Germany . . . the principle of legality ... is thought to imply a principle of compulsory prosecution - a radical attempt directly to eliminate police and prosecutorial discretion altogether.").

85 GrundGesetz Für die Bundesrepublik Deutschland [GRundGesetz] [GG] [Basic Law], May 23, 1949, BGBl. I (Ger.), Präambel.

${ }^{86}$ Richard Frase \& Thomas Weigend, German Criminal Justice as a Guide to American Law Reform: Similar Problems, Better Solutions?, 18 Boston College InT'L \& COMPAR. L. ReV. 317, 319 (1995).

${ }^{87}$ At the trial level, the Federal Prosecution Office has jurisdiction over cases involving espionage, terrorism, treason, and genocide. Shawn Marie Boyne, The German Prosecution SERVICE: GUARDIANS OF THE LAW? 98 (2014). Federal prosecutors have broader appellate responsibility; they represent the state before the Federal Court of Appeals. Id. 
correctional systems. ${ }^{88}$ In each state, the minister of justice is a political appointee who serves in the cabinet, is responsible to the legislature, ${ }^{89}$ and may issue general instructions (Weisungsrecht) that direct prosecutors to handle groups of cases according to a particular policy, ${ }^{90}$ and the ministry also controls the allocation of resources. ${ }^{91}$ As in France, this structure has generated concerns about political influence on the prosecution function. One author has characterized it, at least "on paper," as an "existential threat to prosecutorial objectivity,",92 and the German Judges and Prosecutors Association called on the legislature to abolish the ministers' right to issue instructions. ${ }^{93}$ Moreover, although the ministers seldom direct the handling of individual cases, in practice informal instructions are sometime given and often pertain to cases involving political crimes. ${ }^{94}$ Although prosecutors (like judges) are career civil servants who may not be dismissed for arbitrary reasons once they have completed their probationary service, the ministry's control over certain personnel decisions provides a mechanism to reward or sanction prosecutors in ways that could undercut independent decision making, and this potential is greatest in a few states that regularly rotate prosecutors through different assignments. ${ }^{95}$ Although it appears that political interference in individual cases is infrequent in most states, there have been high profile examples, ${ }^{96}$ and the author of a recent study reported that a majority of the more senior prosecutors she interviewed recalled at least one instance in which they were pressured to handle a case in a certain way.

Caseload pressures and administrative practices have dramatically undermined the traditional German view of the prosecutorial function. In the last 30 years, the traditional principle of mandatory prosecution has gradually given way to a practice of expediency. ${ }^{97}$ In response to rising caseloads in the 1970s and again in the 1990s, the German legislature decriminalized some minor offenses and enacted legislation (discussed below) giving prosecutors new forms of authority to dispose of cases without trial. But these measures have been insufficient to protect German prosecutors from crushing caseloads that make it impossible

${ }^{88} \mathrm{Id}$.

${ }^{89} \mathrm{Id}$. Below the ministry level, the states vary. In most, the regional general public prosecutors are career civil servants, but in four states they are junior political appointees. Id. at 100 .

${ }^{90}$ Id. at 99.

${ }^{91} I d$. at 98-99 (noting that the allocation of resources may reflect a party's platform, and might encourage or frustrate certain types of prosecutions).

${ }^{92} \mathrm{Id}$. at 98 .

${ }^{93} \mathrm{Id}$. at 102 .

${ }^{94} I d$. at 99.

${ }^{95} I d$. at 99-100 (noting the greatest potential for problems in states such as Bavaria and Saxony).

96 The most well-known example involved the prosecutor who charged former Chancellor Helmut Kohl with a serious crime. That prosecutor was given an undesirable new assignment that was formally a promotion, and the charges against Kohl were subsequently dismissed under StPO § 153a. Id. at 99 (citing R. Miller, Germany's Party Finance Scandal "Ends" With Kohl's Plea Bargain and Too Many Unanswered Questions, 2 GERMAN L. J. (2001), available at http://www.germanlawjournal.com/index.php?pageID=11\&artID=60 ).

${ }^{97}$ Shawn Boyne, Is the Journey From the In-Box to the Out-box a Straight Line? The Drive for Efficiency and the Prosecution of Low-Level Criminality in Germany, in THE PROSECUTOR IN TRANSNATIONAL PERSPECTIVE 37, 41 (Erik Luna \& Maryianne L. Wade, eds., 2012). 
for them to carry out their traditional functions. The caseload pressures are most severe in general crime units, where prosecutors receive an average of 120 new cases per month, and in the lower courts, where prosecutors must process 1,000 case files each year. ${ }^{98}$ But other units also experience pressure. For example, a six-lawyer drug trafficking and money-laundering unit prosecuted 3,800 cases in a single year. ${ }^{99}$ The caseload pressures have been exacerbated by the state-level ministries of justice, which adopted time-management practices that track productivity in terms of cases processed and underestimate the complexity of prosecutorial decision making, forcing prosecutors to ration the time they can spend on individual cases. ${ }^{100}$ These workload pressures make it difficult, if not impossible, for prosecutors to conduct a full and objective investigation of each case. Instead, prosecutors operate "as gate-keepers motivated to boost their case processing efficiency.",101

The German legal system has gradually adopted and increased its reliance on discretion to keep the overloaded criminal justice system functioning. Although there were significant legislative changes giving prosecutors significant new forms of discretion, the other critical development occurred without express authorization, as trial courts, prosecutors, and defense attorneys resorted to negotiated judgments as a means of resolving cases, especially complex white collar cases. ${ }^{102}$

The Criminal Code now includes two mechanisms that provide prosecutors with significant charging discretion. Under StPO $\S 153 \mathrm{a}$, prosecutors have discretion to decline to prosecute Vergehen crimes on the basis of their conclusion that there is no public interest in prosecution. Although Verbrechen are sometimes compared to felonies and Vergehen to misdemeanors, ${ }^{103}$ it is important to note that many Vergehen would be felonies in the United States. ${ }^{104}$ For example, almost all business crimes are Vergehen_regardless of the financial harm caused. ${ }^{105}$ Under StPO 153a, the offender must consent to the procedure, and he becomes subject

${ }^{98} I d$.

${ }^{99} I d$. at 46 . Boyne concluded that "[w]ith the exception of a few specialized departments, the bulk of German prosecutors must manage heavy caseloads." Id. at 45.

${ }^{100} \mathrm{Id}$. at 46-47 (describing the hiring of accounting firms to conduct time-management studies of prosecution and discussing the effect on prosecutorial decision making).

${ }^{101} I d$. at 42.

${ }^{102}$ See generally Weigend, supra note 79, at 383-85. Rauxloh traces this development, in part, to the expansion of the criminal code to encompass offenses that require more than simple factual determinations. REGINA RAUXLOH, PLEA BARGAINING IN NATIONAL AND INTERNATIONAL LAW at 64-66 (2012).

${ }^{103}$ See, e.g., Frase \& Weigend, supra note 78, at 320 (using "felony" as a synonym for Verbrechen and "misdemeanor" for Vergehen). The English translation of the Criminal Code uses this terminology, however. StBG $\S 12$, trans. Prof. Dr. Michael Bohlander, including the amendment(s) to the Act by Article 3 of the Act of 2.10.2009 (I Bundesgesetzblatt 3214). In other cases, Verbrechen has been translated as "crime" and Vergehen as "misdemeanor." ${ }^{104}$ RiCHARD FRASE, SENTENCING IN GERMANY AND THE UNITED STATES: COMPARING ÄPFEL WITH APPLES 5-6 (Max Planck Institute, 2001).

${ }^{105}$ Markus Dirk Dubber, American Plea Bargains, German Lay Judges, and the Crisis of Criminal Procedure, 49 STAN. L. REv. 547, 559 (1997). See, e.g., StBG § 263(1) (providing that 
to certain obligations, including the payment of any damages as well as a payment to the Treasury or a charitable organization. Section 153a is used extensively. Additionally, StPO $\S \S$ 407-12 allows a prosecutor to apply to the court for approval of a written penal order

(Strafbefehl). Use of a penal order avoids a trial and concludes the proceedings. The prosecution may apply for a penal order when the results of its investigation suggest a trial is not necessary. A penal order specifies the punishment, which may consist of either a fine, warning, forfeiture, confiscation, public announcement of the order, revocation of driving privileges, or if the defendant is represented by a lawyer, a suspended prison sentence of less than one year. ${ }^{106}$

Despite the traditional norms of the German system, a variety of factors led to the development of a system of negotiated judgments. Various features of German procedure made it especially time consuming to process sophisticated offenses, especially white collar crimes, but quantitative benchmarks for judicial and prosecutorial performance created pressure to resolve these cases quickly. ${ }^{107}$ As a result, practitioners and judges began to settle criminal cases informally. These negotiations were typically initiated by the defense lawyers or judges, not prosecutors (though the latter held an informal veto power). ${ }^{108}$ There was little oversight by appellate courts because the agreements were reached informally off the record, and they typically included a waiver of appeal. However, after a number of cases reached the appellate courts, in 2009 the German legislature adopted a law amending the Code of Criminal Procedure, StPO 257c. ${ }^{109}$ The amendment permits the judges to initiate negotiations and to indicate the maximum and minimum sentences they would be willing to impose as part of an agreed settlement, but it also requires that the court independently find a sufficient factual basis for the judgment and that the sentence reflect the true guilt of the defendant. ${ }^{110}$ StPO 257c also gives the court substantial latitude to later reject the agreement. Despite the tension (if not conflict) with the traditional assumptions upon which the German system is based, in 2013 the German Constitutional Court upheld the constitutionality of StPO 257c, though it did so in a decision that emphasized the limitations the law imposes on negotiations. ${ }^{111}$ One commentary characterized the Court's decision as placing the new law on "probation." 112 It remains doubtful whether the statute, even as interpreted, will be effective in changing entrenched plea negotiation practices that developed in response to workload and administrative pressures. An empirical study solicited by the Constitutional Court and cited in its decision revealed that the current practices diverged widely from the strictures of the statute: for example, 59\% of the judges surveyed stated that they conducted more than one half of their negotiations informally, rather than on the record

fraud is punishable by between zero and five years' imprisonment in normal cases and between six months and ten years' imprisonment in especially serious cases, making fraud a Vergehen). ${ }^{106}$ StPO $\S 407(2)$.

107 See Thomas Weigend \& Jenia Iontcheva Turner, The Constitutionality of Negotiated Criminal Judgments in Germany, 15 GERMAN L.J. 81, 86-87 (2014).

${ }^{108}$ Id. at 87.

${ }^{109} I d$. at 89-91 (providing an English translation of StPO 257c).

${ }^{110}$ Id. at 91-92.

${ }^{111} \mathrm{Id}$. at 94-97.

${ }^{112}$ Id. at 82. 
as required by statute, and in a substantial percentage of cases the judges accepted the prosecution version of the facts without conducting an independent determination. ${ }^{113}$

Despite the legality principle, only a small minority of German cases now go to trial. German prosecutors now rely on the authority of these two provisions to dispose of the majority of cases in which individual suspects have been identified. According to some sources, 70 to 80 percent of all investigations are now terminated with a dismissal or a deferred sentence; these rates vary widely among the German states, ranging from 40 percent in the southern states to 80 percent in some northern states. ${ }^{114}$ In 2009, only one in ten of the cases in which the police referred an identified suspect to the prosecutor's office went to trial; ${ }^{115} 28 \%$ were dismissed for lack of evidence (a determination that itself includes a discretionary determination), and many of the others were dismissed or adjudicated for reasons that even more clearly implicated prosecutorial discretion, including $12 \%$ disposed of by penal order and $26 \%$ dismissed for policy reasons including lack of public interest in the prosecution. ${ }^{116}$ In $2012,77 \%$ of the cases involving known suspects were dismissed under StPO 153a, for lack of sufficient evidence or for policy reasons, and $52 \%$ of the remaining cases were disposed of by penal order. ${ }^{117}$

These procedures are employed even in cases that might be expected to be a high priority. A 2011 review of the implementation of the Organisation for Economic Co-operation and Development (OECD) anti-bribery convention found, for example, that the prosecution was declined under Section 153a in more than half of the cases of foreign bribery between 2006 and $2010 .{ }^{118}$ The OECD review noted that use of Section 153a permitted the imposition of monetary sanctions against numerous individuals, but also expressed concern that the arrangements lacked transparency. ${ }^{119}$

Even broader discretion is recognized in the cases of administrative sanctions. Because German law does not recognize corporate criminal liability, these are the only sanctions applicable to legal persons (corporations, partnerships, and other legal entities). The principle of discretionary prosecution is explicitly recognized in administrative proceedings. ${ }^{120}$ It is thus applicable to any proceedings against legal persons, and to administrative proceedings against natural persons.

\section{Conclusion}

113 Id. at 92-93.

${ }^{114}$ Boyne, supra note 99 , at 44.

${ }^{115}$ Weigend, supra note 79, at 384.

${ }^{116} I d$. at $384-85$.

${ }^{117}$ Weigend \& Turner, supra note 109 , at 84 n. 14.

118 This point was emphasized to the OECD working group which prepared a report on Germany's implementation of the OECD anti-bribery convention. See PHASE 3 REPORT ON IMPLEMENTING THE OECD ANTI-BRIBERY CONVENTION IN GERMANY at 41, available at http://www.oecd.org/germany/Germanyphase3reportEN.pdf .

${ }^{119}$ Id. at 5. Para 3

${ }^{120}$ Id. at 41, para. 120; § 47(1) Gesetz über Ordnungswidrigkeiten of 19 Feb. 1987. 
The stress of heavy caseloads is a reality in each of the three systems, affecting the balance each strikes among the competing goals that are the subject of this chapter. In general, structural features-such as the deliberate fragmentation of prosecutorial authority in the U.S.play a defining role in how each jurisdiction strikes the balance, and these structural features have proven relatively impervious to the pressures created by rapidly rising case loads. In contrast, differences in the training and selection of prosecutors and traditional views of the prosecutorial function have generally played a secondary role, and often given way to the need for greater efficiency. All jurisdictions have responded to the need for more efficient case processing by according prosecutors significant discretion, despite concerns that new mechanisms will be needed to increase reliability. The balance between democratic accountability and prosecutorial neutrality remains contested in all three jurisdictions. Structural features in each system create both the opportunities for disparity in case treatment and the framework for responding to such disparities. Similarly, the structure of prosecutorial authority determines whether and how each jurisdiction can establish priorities and carry out policies.

\section{A. Efficiency and Accuracy}

Caseload pressures are driving all three systems to increase efficiency by giving prosecutors more discretion, even in Germany where discretion is fundamentally at odds with the strong traditional norm of mandatory prosecution. One commentator described this as a tension between traditional dogma and everyday practice in the German system. ${ }^{121}$ Despite their uniform training and professional traditions, German prosecutors have adapted their practices to the reality of caseload pressures and bureaucratic incentives. The German system is still evolving, as both the legislature and the Constitutional Court seek to define a form of plea negotiation under StPO 257c that does not sacrifice core values such as the search for the truth, proportionality in punishment, and transparency of negotiations. It seems doubtful, however, that these efforts will successfully rein in practices that developed without any legislative authorization and now seem well entrenched. Indeed, the Constitutional Court's own survey revealed that practices not permitted by the new legislation were widespread. Further, the survey revealed two aspects in which current practices were contributing to convictions or sentences that could be characterized as inaccurate. Some defendants whose lawyers believed they would not be found guilty confessed after being offered significant sentencing concessions, and a significant number of respondents characterized the negotiated sentences in at least some cases as too low or high. ${ }^{122}$

On the other hand, some commentators have observed that the limitations announced by the German Constitutional Court provide more guarantees of accuracy and fairness than those present in the U.S. plea bargaining system. ${ }^{123}$ In the U.S., efforts to identify the causes of wrongful convictions have identified a variety of recurring problems, including guilty pleas by

\footnotetext{
${ }^{121}$ Boyne, supra note 87 , at 39.

${ }^{122}$ Weigend \& Turner, supra note 97 , at 93.

${ }^{123}$ Id. at 101-05.
} 
innocent defendants. ${ }^{124}$ Recognition that the U.S. system is now more administrative than adversarial has led to widespread support for modifying the structure of prosecutors' offices to increase both accuracy and efficiency in the initial processing of cases, ${ }^{125}$ and in the reassessment of convictions in which there may have been an error. ${ }^{126}$

\section{B. Democratic Accountability and Prosecutorial Neutrality}

All three national systems have structural mechanisms designed to provide a degree of democratic accountability. The issue in both is how to balance the need for accountability with the commitment to prosecutorial neutrality and independence, especially in cases involving the investigation of politically prominent suspects who are members-or opponents-of the current government.

In both France and Germany the oversight of the ministry of justice holds the potential for political interference with the prosecution function. In France, many serious white collar cases appear to have a significant political element. ${ }^{127}$ Charges of political influence in high profile cases provoked sufficient controversy that legislative changes were adopted in 2013 to insulate prosecutorial decision making in individual cases from control by the Ministry of Justice. $^{128}$ It is too soon to say how successful these changes will be in protecting the independence of prosecutorial decision making and in restoring public confidence. In Germany, the issue of political influence seems to have less current salience, and the legislature did not adopt changes sought by the union of prosecutors and judges. ${ }^{129}$ On the other hand, a survey of

${ }^{124}$ See generally BRANDON L GARRETT, CONVICTING THE INNOCENT: WHERE CRIMINAL PROSECUTIONS GO WRONG (2011) (identifying contaminated confessions, eyewitness misidentification, flawed forensic analysis, and perjury by jailhouse informants and others as factors in the largest number of false convictions, but also noting that guilty pleas by innocent defendants and prosecutorial misconduct played a role in multiple cases). ${ }^{125}$ See generally Rachel E. Barkow, Institutional Design and the Policing of Prosecutors: Lessons from Administrative Law, 61 STAN. L. REV. 869 (2009).

${ }^{126}$ See, e.g., Establishing Conviction Integrity Programs in Prosecutors' Offices at 5, 13-14, 4648 (recommending establishment of conviction integrity units and providing examples from Manhattan District Attorney's conviction integrity unit), available at http://www.law.nyu.edu/sites/default/files/upload_documents/Establishing_Conviction_Integrity Programs_FinalReport_ecm_pro_073583.pdf.

${ }_{127}$ For example, following the defeat of President Nicolas Sarkozy's bid for reelection there have been high profile criminal investigations of persons connected to Sarkozy, including Bernard Tapie, a businessman who began as a Socialist but switched his allegiance to the center-right Sarkozy's Union for a Popular Movement. Investigators are reportedly seeking to learn why the government did not challenge a $€ 403$ million award to Tapie that settled a long-running dispute with Crédit Lyonnais, a state-owned bank. The investigation has also entangled the chief executive of France Télécom as well as Christine Lagarde, the managing director of the International Monetary Fund. See David Jolly, Role of France Télécom Chief in Tapie Affair to Be Investigated, N.Y. Times, June 12, 2013.

${ }^{128}$ See supra notes 51-60 and accompanying text.

${ }^{129}$ See supra note 95 and accompanying text. 
senior prosecutors found that the majority felt pressure in some individual cases, and the personnel policies in several states make them especially vulnerable to such pressures. ${ }^{130}$

Similar concerns about politically motivated prosecutions and interference with prosecutorial decision making in individual cases have also arisen intermittently in the U.S. Critics have identified evidence of occasional partisan influences on the exercise of prosecutorial discretion in the federal system. ${ }^{131}$ These issues arise most frequently in federal cases for a variety of reasons: most white collar cases (including cases involving political corruption or sophisticated financial crimes) are prosecuted in the federal courts, federal law includes a bewilderingly large number of offenses, many of which are defined in very broad terms, and federal prosecutors have ample investigative resources (including the powers of the grand jury) to develop cases. Despite calls for reform, the design of the U.S. constitution-which allocates all federal executive authority to the president-limits the degree to which the prosecutorial function can be insulated from the control of the president and his political appointees. There have been two significant legislative efforts to address these issues. The first was the creation of an inspector general within the Department of Justice. ${ }^{132}$ The second was the creation of the office of the special prosecutor (subsequently renamed independent counsel), who was given independence from the Department of Justice and Attorney General so that it could pursue investigations and prosecutions against senior officials within the Administration free of political interference or conflicts of interest. ${ }^{133}$ The independent counsel legislation was allowed to lapse in 1999, and subsequent individuals designated as "independent counsel" have been appointed by the Attorney General pursuant to Departmental regulations. ${ }^{134}$ The controversy surrounding the Bush administration's firing of multiple U.S. Attorneys demonstrated another constraint on the misuse of prosecutorial authority for political purposes: the firings provoked a storm of controversy that led to oversight hearings in Congress, reports by the Inspector General, and sustained investigation and commentary by the press. ${ }^{135}$

\section{Consistency and Equal Treatment}

Although it appears that all national systems regard the equal (as well as fair) treatment of defendants as a goal, it is in tension with many of the other goals and features of the three national systems.

The present system in the U.S. produces at least two forms of disparity. The first is the consequence of the exercise of discretion on a case-by-case basis by individual prosecutors in the absence of clear standards. The emergence of prosecutorial discretion over charging, diversion, and plea negotiations in all three systems makes this form of discretion nearly inevitable unless

130 See supra notes $96-98$ and accompanying text.

${ }^{131}$ See Beale, supra note 4, at 382-90 (discussing statistical evidence of disparity as well as individual prosecutions).

${ }^{132} I d$. at $412-13$.

${ }^{133}$ Id. at 413 .

${ }^{134}$ Id.

${ }^{135}$ For a discussion of the controversy and the broader issues it raised, see generally Beale, supra note 4. 
there are specific (rather than broad general) guidelines and/or required supervisory review and approval. Although prosecutorial guidelines are increasingly common, in many cases the guidelines are stated in such general terms that they do not provide clear standards in individual cases. If only a small percentage of possible cases can be prosecuted, as is often the case in the U.S. federal system, the result is predictable disparity, a kind of negative lottery among defendants who have committed offenses that could be prosecuted in the federal courts. ${ }^{136}$

When chief prosecutors set different priorities or adopt different practices for their respective jurisdictions, this creates a second kind of disparity. This form of disparity is immediately evident in the U.S. system, where prosecutorial authority is deliberately fragmented, and elected chief prosecutors are expected to take varying approaches that reflect not only local conditions but also the attitudes and concerns of the people the prosecutor represents. There is no expectation that all elected prosecutors in a state will have the same enforcement priorities and policies. There are dramatic differences, for example, in the enforcement of the so-called "three-strikes" laws and other mandatory minimum sentencing statutes, and in the willingness to seek the death penalty. This expected variation is also an important feature of the federal system, which envisions states not only as distinct political communities with the right to selfgovernment, but as also laboratories in which different laws and policies may be tested. On the other hand, the federal government, with its unitary executive, provides a hierarchical national structure that could be employed to increase consistency among cases falling within federal jurisdiction (just as the federal Sentencing Guidelines were intended to ensure that similarly situated offenders convicted of the same offense would receive consistent sentences in the federal courts). Traditionally, however, the standards governing the discretion of federal prosecutors have been stated in very general terms, and central approval is now required only in death penalty cases and a few other kinds of prosecutions. ${ }^{137}$ The overlap of the federal and state criminal justice systems creates the potential for yet a third form of disparity, between defendants who engaged in the same conduct, but may be prosecuted in the federal system (which generally imposes longer sentences), the state system, or both. ${ }^{138}$

There is evidence that disparity also arises in both France and Germany as a result of variations in the practices and priorities of prosecutors' offices. In France, although the hierarchical national structure of the prosecution and the promulgation of circulars and other guidance from the Ministry of Justice are intended to promote uniformity, observers have detected regional variations. ${ }^{139}$ On its face, the French National Assembly's creation of a new white collar prosecutorial position appears to be an effort to enhance and centralize the approach to such cases, but critics have argued that the measure was unnecessary and may even be counterproductive. ${ }^{140}$ In Germany, as the de facto discretion exercised by prosecutors has

${ }^{136}$ See generally Sara Sun Beale, Too Many and Yet Too Few: New Principles to Define Proper Limits for Federal Criminal Jurisdiction, 46 HASTINGS L.J. 979 (1995).

137 See supra notes 28-31 and accompanying text.

${ }^{138}$ See Beale, supra note 139, at 1003-04, (noting the irony of the federal/state disparity that resulted from the imposition of federal sentencing and guidelines which aimed to provide more uniformity in sentencing).

139 See supra note 66 and accompanying text.

${ }^{140}$ See supra notes 56-61 and accompanying text. 
increased, the allocation of all enforcement authority to the states has given rise to significant variation at the state and regional level in the treatment of common offenses. ${ }^{141}$ It is difficult to reconcile these variations with the traditional norms of full prosecution and proportional punishment that reflects the true facts of each case.

The disparities that occur in the French and German systems appear to lack the strong normative justifications that undergird the deliberate fragmentation of prosecutorial authority in the U.S. France's hierarchical national structure does not value or promote regional differences. Germany allocates most criminal law enforcement to its states, but this division of authority over criminal law does not necessarily reflect all of the same values and assumptions as American federalism and the further deliberate fragmentation of authority at the state level in the U.S. Although this delegation is surely intended to allow prosecutors in each state to respond to significant differences in local conditions, it is questionable whether it is intended to authorize divergent views on policy issues. The structure of Germany's federal and state courts ${ }^{142}$ and the general understanding of German criminal law ${ }^{143}$ reflect an understanding that federal criminal laws will be applied uniformly in the various states. A degree of prosecutorial discretion has been introduced to provide a means of responding to rising caseloads, not in order to promote variations among the states.

\section{Mechanisms for Setting Policies and Priorities}

Finally, the three systems vary in their capacity to reconcile the need to establish policies

${ }^{141}$ See supra at 9 and notes $97-103$ and accompanying text.

142 The allocation of powers and duties among federal and state courts strongly suggests that the administration of criminal justice is meant to be functionally federal.

While the Länder have an important role in performing judicial functions, the German legal system is characterized by the dominance of federal law. Court organization, boundaries, and procedures are generally regulated by federal law. Except for the Land constitutional courts, pay and benefits are set by federal law. The interpretation of constitutional law and of ordinary federal law are basically left to the Federal Constitutional Court and the federal superior courts. All of this leads, of course, to the uniformity of judicial decision making in the German federal system.

ARTHUR B. GUNLICKS, THE LÄNDER AND GERMAN FEDERALISM 72 (2003). Although the courts are mostly Land courts, "in the final analysis the federation is the dominant partner in judicial matters." Id. at 73. The effective federal nature of the courts suggests the law is meant to be the same in every state

${ }^{143}$ German criminal law, when compared to the British and American traditions, is "deductive," "heavily doctrine-driven," and "based on the more or less strict application of logic and welldeveloped methods of interpretation." MiCHAEL BOHLANDER, PRINCIPLES OF GERMAN CRIMINAL LAW 7, 9 (2009). Unlike in many common law systems, in German criminal law one finds no juries and no magistrates, and there is no corresponding need to ground legal reasoning in common sense. Id. at 7. Because judicial focus rests on the law more heavily than policy or other logic external to the statutes, the source of the law matters more in Germany than the United States. And because the source of the law is national, criminal law is in this way intentionally national. Any departure from national uniformity may be suspect as pollution in the doctrine. 
and priorities without intruding on prosecutorial neutrality and independence. The uniform and hierarchical French national system seems to have the greatest ability to achieve these goals. As noted above, the French system gives the Minister of Justice the authority to set priorities and policies. ${ }^{144}$ Although the legislation adopted in 2013 limits the Minister's control of individual prosecutions, ${ }^{145}$ it does not restrict his general authority over the criminal justice system.

In Germany, in contrast, enforcement authority is allocated to the states. Although individual states may be able to establish priorities and policies and state ministers of justice may issue general instructions, the national government seems to lack that capacity, even in the case of cases involving national treaty obligations. As a review of enforcement of the OECD convention on combatting foreign bribery noted, the power to investigate and prosecute are devolved to the states, "and the federal authorities have no supervisory powers."146

Paradoxically, the fragmented U.S. system provides a mechanism for uniform policy making in a very limited class of cases. Like Germany, the U.S. has allocated most general enforcement authority to the states, but with a critical difference: five to ten percent of U.S. felony cases are prosecuted by federal prosecutors in the federal courts, ${ }^{147}$ and federal enforcement dominates some important fields, such as offenses involving political corruption and financial crimes. Although centralized review and control of certain prosecutions is the exception rather than the rule even within the federal system, it is significant. For example, the unitary structure of the executive itself provides a mechanism for establishing uniform standards for the prosecution of foreign corruption as required by common treaty obligations. The U.S. Attorneys' Manual allows only the fraud section of the Criminal Division in Washington to prosecute cases foreign corruption cases under the FCPA. ${ }^{148}$ No similar mechanism is available within most states, which lodge all authority in the thousands of elected local prosecutors. Another feature of the U.S. structure provides a possibility that the federal government may occasionally override the decision of state prosecutors (and also state legislatures). Although there are very few capital cases in the federal system, in a small number of cases the availability of the federal death penalty may counteract the inequality that results from differences in state law or the willingness of state prosecutors to seek the death penalty. For example,

Massachusetts state law does not authorize the death penalty, but a federal indictment was filed charging use of a weapon of mass destruction and Attorney General Eric Holder authorized federal prosecutors to seek the death penalty in the case of the man accused of killing and maiming people with homemade bombs at the Boston Marathon. ${ }^{149}$

\footnotetext{
${ }^{144}$ See supra notes 41-43, 72 and accompanying text.

145 See supra notes 51-54 and accompanying text.

146 TransPARENCY INTERNATIONAL, EXPORTING CORRUPTION, PROGRESS REPORT 2013: ASSESSING ENFORCEMENT OF THE OECD CONVENTION ON COMBATTING FOREIGN BRIBERY at 44 (2013), available at http://issuu.com/transparencyinternational/docs/2013_exportingcorruption_oecdprogre .

${ }^{147}$ See supra note 23 and accompanying text.

148 See supra note 29 and accompanying text.

${ }^{149}$ Matt Apuzzo, U.S. Is Seeking Death Penalty in Boston Case, N.Y. Times, at A1, Jan. 30, 2014
} 